\title{
Context, market economies and MNEs: the example of financial incentivization
}

Article

Accepted Version

Creative Commons: Attribution-Noncommercial-No Derivative Works 4.0

Walker, J., Wood, G., Brewster, C. and Beleska-Spasova, E. (2018) Context, market economies and MNEs: the example of financial incentivization. International Business Review, 27 (1). pp. 21-33. ISSN 0969-5931 doi:

https://doi.org/10.1016/j.ibusrev.2017.04.006 Available at https://centaur.reading.ac.uk/73065/

It is advisable to refer to the publisher's version if you intend to cite from the work. See Guidance on citing.

Published version at: http://www.sciencedirect.com/science/article/pii/S0969593117303116

To link to this article DOI: http://dx.doi.org/10.1016/j.ibusrev.2017.04.006

Publisher: Elsevier

All outputs in CentAUR are protected by Intellectual Property Rights law, including copyright law. Copyright and IPR is retained by the creators or other copyright holders. Terms and conditions for use of this material are defined in the End User Agreement.

\section{www.reading.ac.uk/centaur}

\section{CentAUR}

Central Archive at the University of Reading 
Reading's research outputs online 


\title{
Context, market economies and MNEs: The example of financial incentivization
}

\begin{abstract}
:
This is a study of the impact of variety on the relative utilization of reward systems within and between capitalist archetypes: The study includes not only a closer focus on variety within and between coordinated market economies, but pays specific attention to the Japanese case, and a systematic comparison of the reward practices adopted by Multinational Enterprises vis-à-vis their local peers. The study uses the most recent wave of the international Cranet survey of HRM, and contrasts this with studies based on previous waves.
\end{abstract}

Key words: varieties of capitalism; institutions; incentivization; share ownership schemes; performance related pay; MNEs.

\section{INTRODUCTION}

This is a study of the impact of institutional variety on the relative utilization of reward systems within and between capitalist archetypes. A central theme within the extensive literature on comparative capitalisms has been the distinction between Liberal Market Economies (LMEs) and Coordinated Market Economies (CMEs), and how defining institutional arrangements in each are associated with distinct patterns of firm level practice (Hall \& Soskice 2001; Hancke et al. 2007; Wood et al. 2014; Jackson \& Deeg 2008). We explore not only the variations between market economies, but also how different manifestations of the CMEs can yield quite different results at firm level. We explore the interaction of multinational enterprizes with these market economies.

A key distinction between types of capitalism is the relative influence of shareholder rights, which are dominant in LMEs but which, within CMEs, are mediated by other stakeholder 
concerns. Controversy remains as to whether the CME category, encompassing such cases as Germany, the Nordic states and Japan, is so diverse as to be meaningless, and whether this category should itself be broken up into distinct sub-archetypes (Amable, 2003). The comparative capitalisms literature has also been critiqued (Whitley, 2001, 2010; Wood \& Lane, 2012) for the limited attention it gives to the role of multinational enterprises (MNEs). We examine the extent to which variations in national institutional regime and in geographical footprint are reflected in employee share ownership schemes and performance related pay aiming to promote a focus on short term profits and align employees with the shareholder value agenda. We use comparative surveys of human resource management (HRM) across a number of countries and compare the findings with previous research.

The international business literature on institutions has focused more on the implications for firms of entering and operating in a particular context, rather than the defining features of national institutional frameworks and upon which specific sets of organizational practices are clustered where (Jackson \& Deeg, 2008). Although the literature on comparative capitalisms has identified a range of institutional archetypes, it has tended to be light on detail when it comes to intra-organizational practices (Thompson \& Vincent, 2010; Wood et al., 2014). Existing comparative work has focused on the degree of interdependence of employers and employees, and the extent of delegation to the latter (Morgan \& Whitley, 2012; Thelen, 2014; Whitley, 1999). Within both the international business and comparative institutionalist literatures, and indeed, the international HRM literature, comparative analysis has neglected reward systems (Festing, et al., 2012).

What comparative literature there is has focused on macro-economic trends or selective case study evidence (Thompson \& Vincent, 2010; Wood, Brewster \& Brookes, 2014) with a nascent stream of work using survey evidence that has focused on, and encountered, variations in 
rewards between states, with some studies also looking at the cases of Eastern Europe and the Mediterranean world (Croucher et al., 2012, Brewster et al., 2013; Pendleton et al., 2003; Poutsma \& De Nijs, 2003). A recent paper by Gooderham et al. (2015) deploys multi-level analysis to explore variations in reward systems, using the same Cranet dataset as this paper. They find that institutional and cultural effects directly impact on the relative utilization of pay for performance systems, with such systems being most prevalent in the USA (Gooderham et al., 2015).

The distinctive contribution of this article is that it is more closely rooted in the literature on comparative capitalisms, with a particular focus on variety within the CME category. In particular, we seek to evaluate what sets Japan apart; we also explore more closely the distinct features of the Nordic states.

Further, as noted above, much of the literature on comparative capitalism tends to neglect MNEs: Notably, there is not a single reference to them in the landmark Hall and Soskice (2001) collection. This study aims to build linkages between this undeniably important body of work and mainstream international business research by placing the distinctions between MNEs and other firms at the heart of the analysis. As such, the study seeks to provide applied evidence as to variation within broad capitalist archetypes, how firms that span national boundaries differ in key aspects of reward systems, and the relative extent to which the latter may serve to align different categories towards particular agendas that may be at least partially driven by context (e.g. shareholder value optimization).

Hence, we build on the literature through using trans-national survey evidence to explore not only variations in reward systems within and between firms, but also the extent to which they may vary according to national setting, and what this tells us about different taxonomies of capitalist archetypes, according particular attention to variation and sub-clusters within the 
CME camp, following on increased theoretical interest in that issue (Amable 2003; Jackson \& Deeg 2008; Wood et al. 2014). We find that dichotomous approaches to comparative capitalisms were of weaker explanatory power than multi-archetype approaches that unpack the CME category. Most notably, we find that both the Nordic Social Democracies on the one hand, and Japan on the other, differ significantly in their financial incentivization practices from Continental European Economies. We also note and discuss the distinctive position of MNEs, a firm type that has rather been neglected in the literature on comparative capitalisms. It is only in recent extensions of Business Systems Theory that the MNE has received significant theoretical attention (Morgan, 2012; Whitley, 2007): We seek to apply these relatively recent theoretical insights to firm level evidence.

The paper is structured as follows. First, we introduce alternative institutional archetypes for categorizing national settings. Second, we review general trends in reward systems, explore likely variations in the utilization of share options and performance based pay systems according to different national setting, and identify a set of hypotheses. Third, we examine the role of MNEs. After explaining the survey method and data analysis, we outline and discuss our findings, before presenting our conclusions and drawing implications.

\section{LITERATURE REVIEW}

\subsection{National institutional archetypes}

The most cited literature on comparative capitalisms holds that the key distinction is between LMEs (the Anglo Saxon countries) and CMEs (the Rhineland economies, Japan and the Nordic states) (Hall \& Soskice, 2001; Dore 2000). The former are distinguished by strong shareholder rights, the latter by strong stakeholder rights. Only these two models were believed to confer particular competitive advantage on firms. Other economies, it was held, are less successful and would tend to converge to one or other of these alternative models. Wood et al. (2014) 
found much variation between national varieties of capitalism, highlighting the need for a closer evaluation as to what sets different constituent national economies apart.

Recent developments of the literature on comparative capitalisms have indicated much variation within and between capitalist archetypes (Lane \& Wood, 2014; Walker et al., 2014). In an early contribution, Whitley (1999) distinguishes between European CMEs and Japan, based on the relatively greater role of large firms in the latter, and the impact of historical ties such firms have with the state in regulating work and employment. Analyzing an eclectic range of empirical evidence, from labor market features through training to product market competition, Amable (2003) derives five categories, rather than two. Apart from the LMEs (which he calls market based systems) he splits the CME category into 'meso-corporatist' Japan, the Nordic Social Democratic Economies (SDEs) ${ }^{\mathrm{i}}$ and the Rhineland economies ('Continental European Economies'). He also identifies a distinct Mediterranean category that falls beyond the scope of this study.

\subsection{Defining features of national systems: In-firm practices}

Whitley (1999) argues that key differences between national contexts include the degree of interdependence between employer and employee and the extent to which firms delegate decision making to the latter. While encompassing large areas of work and employment relations, and providing a basis for detailed empirical differentiation between capitalisms (Croucher, et al., 2012; Goergen, et al., 2012), this approach neglects perhaps the most basic issue of all - the relative proportion of value generated that is allocated to employees in return for work performed, and the manner in which it is done (Hyman, 1989; Wood et al., 2014). Indeed, a defining feature of LMEs is their focus on shareholder value, and on incentivizing managers to maximize short-term performance in this area (Dore, 2000), facilitating the firm in transferring much of the risk of market volatility to employees. Such risks may encompass, 
with weaker organizational performance, the possibility of reduced pay and/ or the loss of employment completely.

But, how do different types of capitalism differ in terms of firm practices? There is only a limited literature on the comparative capitalisms and reward systems. However, there are many excellent country studies on national trends in the practice of reward as well as comparative frameworks typically using inductive country categorizations, which we summarize in Table 1.

Table 1: Variety in Capitalism and Rewards

\begin{tabular}{|c|c|c|c|}
\hline $\begin{array}{l}\text { Domain } \\
\text { Theoretical } \\
\text { Framework }\end{array}$ & $\begin{array}{l}\text { Capitalist } \\
\text { Archetype }\end{array}$ & $\begin{array}{l}\text { Share } \\
\text { Ownership } \\
\text { Schemes }\end{array}$ & $\begin{array}{l}\text { Performance } \\
\text { Based Pay }\end{array}$ \\
\hline \multirow{2}{*}{$\begin{array}{l}\text { Varieties of } \\
\text { Capitalism } \\
\text { (Hall and } \\
\text { Soskice 2001) }\end{array}$} & $\begin{array}{l}\text { Liberal Market } \\
\text { ('Comparatment- } \\
\text { alized') }\end{array}$ & High (1) & High (1) \\
\hline & $\begin{array}{l}\text { Coordinated } \\
\text { Market }\end{array}$ & $\begin{array}{l}\text { Moderate to Low } \\
\text { (2) }\end{array}$ & $\begin{array}{l}\text { Moderate to } \\
\text { Low (2) }\end{array}$ \\
\hline \multirow{3}{*}{$\begin{array}{l}\text { Business } \\
\text { Systems Theory } \\
\text { (Whitley 1999) }\end{array}$} & Liberal Market & High & High \\
\hline & $\begin{array}{l}\text { Coordinated } \\
\text { Market } \\
\text { ('Collaborative') }\end{array}$ & Moderate to Low & $\begin{array}{l}\text { Moderate to } \\
\text { Low (2) }\end{array}$ \\
\hline & $\begin{array}{l}\text { Asian Capitalism } \\
\text { ('Highly } \\
\text { Coordinated') }\end{array}$ & $\begin{array}{l}\text { Moderate to } \\
\text { High (4) }\end{array}$ & $\begin{array}{l}\text { Moderate to } \\
\text { High (4) }\end{array}$ \\
\hline \multirow{4}{*}{$\begin{array}{l}\text { Social Systems } \\
\text { of Production } \\
\text { (Amable 2003) }\end{array}$} & $\begin{array}{l}\text { Liberal Market } \\
\text { ('Market Based') }\end{array}$ & High & High \\
\hline & $\begin{array}{l}\text { Continental } \\
\text { European } \\
\text { Capitalism } \\
\end{array}$ & $\begin{array}{l}\text { Moderate to Low } \\
\text { (3) }\end{array}$ & $\begin{array}{l}\text { Moderate to } \\
\text { Low (3) }\end{array}$ \\
\hline & $\begin{array}{l}\text { Social } \\
\text { Democratic } \\
\text { (Scandinavian) } \\
\text { Capitalism }\end{array}$ & Low (5) & Low (5) \\
\hline & $\begin{array}{l}\text { Asian Capitalism } \\
\text { (coordinated } \\
\text { market) }\end{array}$ & $\begin{array}{l}\text { Moderate to } \\
\text { High }\end{array}$ & $\begin{array}{l}\text { Moderate to } \\
\text { High }\end{array}$ \\
\hline
\end{tabular}

(1) D’Art \& Turner, 2004; Pendleton, et al. 2001; Bender 2004. 
(2) Soskice et al. 2009; Pendleton et al. 2001; Poutsma et al 2012.

(3) Poutsma et al., 2012; Aumayr, et al., 2009, Kurdelbusch, 2002

(4) Driffill, 2006; Calmfors \& Driffill, 1988.

(5) Driffill, 2006.

\subsection{Types of Variable Pay}

In relation to equity-based pay, there are considerable differences between managers and other stakeholders. Managers are likely to possess better information as to the actual capabilities, performance and prospects of their organization than either workers or outside investors (Aoki, 2010). In contexts where shareholder rights are stronger, outside investors are likely to respond by seeking to tie managerial rewards to share price (Dore, 2000; Hall \& Soskice, 2001) and there are strong inherent pressures towards incorporating stock options in managerial reward packages (Folkman, et al., 2007) ${ }^{\mathrm{ii}}$. In contrast, share schemes aimed at other categories of employee may fulfill a range of objectives in addition to, and distinct from, maximizing shareholder value. These can include broadening the ownership base of the firm in order, for example, to make privatizations more palatable, encouraging employees to stay with the firm, offsetting pay restraint, or indeed, making the firm more accountable to employees as stakeholders. Reflecting this, there is much diversity in how such schemes are operationalized; variations can include the extent to which employee shares are held in trust, the relative voting rights assigned to employees, and the scale and proportion of shares assigned to employees (Morris et al. 2005). Hence, we separate out narrow share ownership schemes aimed at senior managers from those broader schemes aimed at other categories of workers.

Unlike such share schemes, which are rarely formally covered in written employment contracts, except among senior executives (Poutsma \& de Nijs, 2003: 865), performance related pay schemes (individual cash bonuses for meeting or exceeding agreed targets) may be part of the explicit contract and constitute an immediate proportion of pay. Individual 
performance based pay may be targeted at specific categories of employees or an entire workforce (D’Art \& Turner, 2004; Pendleton, et al. 2001). Organizational performance may or may not be related to the performance of the employees - external market conditions may play a significant role. In practical terms, this means that whilst rank and file employees may benefit from more performance based reward systems, they will at the same time seek to regulate pay systems to prevent the risks of poor organizational performance being shifted on to them. Whilst employees as a collective are stronger in dealing with the organization than they are as individuals, the former will often sacrifice the possibility of exceptional individual rewards for collective and standardized pay (Kerrin \& Oliver, 2002).

For all staff such pay is an attempt to link remuneration to performance. But it may not be effective, particularly for managers: Such schemes may be rather opaque, with executives sometimes being able to secure large bonus payments even in the face of abject failure (Kolb, 2012: 23). Hence, we distinguish between managers and other categories of employee.

\subsection{Varieties of Reward System}

What is likely to be the impact of different varieties of capitalism on reward systems? We examine this successively for each of four categories (LMEs; CMEs; Japan; and the SDEs), distinguishing between hypotheses that relate to share ownership schemes as ' $a$ ' and performance related pay as ' $b$ '.

What sets LMEs apart from all other types of capitalism is that the latter, either owing to stronger institutional constraints and countervailing stakeholder power (in the case of Continental European Economies), or less closely aligned institutions (in the case of less mature economies), are associated with weaker owner rights (Dore, 2000; Hall \& Soskice, 2001). Given the primacy of owners/ shareholders in the LMEs, this raises the issue of how they deploy their power to align managers with their returns maximization agenda (Dore, 2000; 
Hall \& Soskice, 2001). The most obvious manner in which this can be achieved is by tying managerial pay to the share price (Folkman et al., 2007). We might therefore expect that such schemes will be used more in LMEs than they are in economies where competing interests have more legitimacy and rights (Dore, 2000). Further, it seems likely that the greater credibility of share schemes in the LMEs will spill over into a greater acceptability of such schemes for a wider group of employees so that there will also be a difference between LMEs and CMEs (Continental European Economies; Japan; Social Democratic Economies) in the utilization of share ownership schemes aimed at other categories of employee. Gunnigle et al. (1998) argue that performance related pay is a feature of individualized work and employment relations, and indeed, is a mechanism for constraining the influence of employee collectives. Bender (2004) argues that firms are more likely to use performance related pay aimed at senior managers in contexts where there is a desire to 'optimize' managerial performance through the prospect of high incomes. Since firms tend to mimic their peers in order to remain competitive recruiters, whether such schemes work or not, they are seen as legitimate in such environments (Bender, 2004).

\section{Hypothesis 1a. Share ownership schemes will be more common in LMEs than in other capitalist archetypes.}

\section{Hypothesis $1 b$. Performance related pay will be more common in LMEs than in other capitalist archetypes.}

In the Coordinated Market Economies (CMEs) owner rights are mediated through the greater power of other stakeholder interests, including employees (Amable 2003; Hall \& Soskice, 2001; Dore, 2000). More patient investors with longer-term horizons have less interest in incentivizing managers to pursue short term shareholder value. Rather, the concern would be to ensure that the organization survives. So stock options for managers are less likely than in 
LMEs. Hall \& Thelen (2009) argue that these markets are undergoing change, with a tendency towards dualism and segmentation but that nevertheless key institutional features retain their importance. Before 1998 stock options were illegal in Germany and they are still often targeted at groups rather than individuals when it comes to non-managerial employees (Casper, Lehrer \& Soskice, 2009). Whilst there has been considerable take up of stock options across continental Europe, they still constitute a smaller proportion of managerial pay than typically encountered in LMEs (Poutsma et al. 2012; Coffee, 2005). Such individual contingent rewards supplement, rather than supplant, traditional collectivist arrangements (Kurdelbusch, 2002).

A gradual dissemination of individual incentive based pay systems may be taking place across continental European states (Aumayr, et al., 2009). Festing et al. (2012: 139) suggest that, in some countries, additional or bonus payments may in reality be non-discretionary and performance neutral, an example being the widespread use of Christmas 'bonuses', a de facto mechanism of partial pay deferral masked as bonuses, which does not link rewards to overall organizational performance or workers' individual achievements (Kurdelbusch, 2002: 326). Looking at genuine performance related pay, Kraft \& Ugerkovic (2006: 334) found that "only a small fraction of firms consider introducing such a scheme", probably reflecting the extent to which such schemes really suit their needs and, it could be argued, known outcomes flowing from collectivist arrangements. Pendleton et al. (2001) suggest that in such settings, broad based schemes of this type remain relatively uncommon (in contrast to individual or narrow based share ownership schemes supplementing existing arrangements). Hence:

\section{Hypothesis 2a. Share ownership schemes will be less common in CMEs than in} LMEs.

\section{Hypothesis 2b. Performance related pay will be less common in CMEs than in} LMEs. 
One of the limitations of the early literature on comparative capitalisms was the relative size and variation within the CME category. Japan is commonly included (Hall \& Sockice, 2001), but Amable (2003) and Whitley (1999) suggest it represents an archetype in its own right. Indeed, the classic Calmfors \& Driffill (1988) model of wage bargaining held that Japan is a highly decentralized system, with rewards often set at the individual level. At least when it comes to wage setting, Japan is on a par with LMEs such as the USA in this regard (Driffill, 2006).

Recent theoretical work on Japan has argued for increased liberalization there too, either because of the influence of the increased foreign ownership of large multinationals (Malcolm, 2013; Sako \& Kotosaka, 2012), or because of the pressures towards lower value added production paradigms facilitated through offshoring to China undermining existing coordinated mechanisms - liberalization by proximity (Wood, 2013). Both accounts point towards the differences between LMEs and Japan eroding and there is evidence of increased support for performance based pay amongst younger workers (Lee, et al., 2011) with perhaps two thirds of companies making use of performance related pay (Suzuki \& Kubo, 2011). Since the 1997 reforms legalizing share ownership plans, a gradual dissemination of such schemes across Japan has been promoted as contributing directly to organizational performance (Kato et al., 2005). Given that wage determination was traditionally quite decentralized in Japan (Calmfors \& Driffill, 1988), this might suggest that this is one area where the difference between Japan and the LMEs is now the least pronounced.

\section{Hypothesis 3a. Share ownership schemes are as common in Japan as in the LMEs}

\section{Hypothesis 3b. Performance related pay is as common in Japan as in the LMEs}

As noted above, Amable (2003) suggests that the Nordic social democracies are distinct from CMEs and that the differences between them and the CMEs are as great as those with LMEs. 
He argues (2003, p. 301) that of lesser importance than how rewards are structured is the relative extent of collective bargaining. At the very least, the latter will impose minima in terms of core wage rates even if supplemented at plant level by one or other form of bonus. For Amable (2003: 94), centralized wage bargaining will affect not only wage rates, but also how wages are structured, "solidaristic wage setting". A strong emphasis on equity between firms, rather than the economic situation of the individual firm, is most conspicuous in the SDEs (Driffill, 2006). This would be at odds with share ownership schemes. Such wage setting gives real incentives to firms to enhance productivity, since they have limited room to increase profits through cutting wages. This is not necessarily dependent on centralized bargaining, as institutional devices such as wage policy proposals by national unions or employers' associations may also promote coordination (Amable, 2003, p. 95). Hence, it can be argued that both share ownership and contingent individual performance related pay will be lower in the SDEs than in other types of capitalism.

\section{Hypothesis 4a. Share ownership schemes will be less common in SDEs than in other types of capitalism.}

\section{Hypothesis 4b. Performance related pay will be less common in SDEs than in other types of capitalism.}

\subsection{MNEs: crossing institutional domains}

Morgan (2012) argues that when operating abroad, MNEs straddle institutional domains, and are less rooted to or tied by institutional restraints in their country of domicile than their local counterparts. Ties and relationships linking them to local actors and interest groupings are less dense, allowing for greater room to maximize returns to headquarters than domestic, more deeply embedded firms (Morgan, 2012; Whitley, 2007). It has been argued that MNEs may play a key role in promoting practices associated with LMEs (Sako \& Kotosaka, 2012; Dore 
2008). MNEs may not discover, or be inclined to utilize, the full range of benefits accruing from national institutional frameworks, and may be more willing to depart from nationally dominant ways of doing things (Dörrenbächer \& Geppert, 2011; Williams \& Lee, 2011). Furthermore, one of the sources of competitive advantage of MNEs is their ability to transfer organizational practices, including HRM practices, across their geographically dispersed operations, even if the dimensions of practice transfer are influenced by different mechanisms, and in the case of HRM practices, subsidiary embeddedness in the local institutional context seems to play an important role (Ahlvik \& Björkman, 2015). The evidence base is incomplete and somewhat contradictory: Geppert et al (2013) found that in Germany, there were stronger restraints on adopting practices from abroad than in the UK, an LME. Lavelle et al. (2012) found considerable diversity in MNE practice, according to organizational characteristics, country of origin, sector and whether a firm was unionized or not. Gooderham et al. (2015) find that MNEs were more likely to drive performance based pay systems, suggesting that they are less bound by the constraints imposed by any single context. We capture both the location of the firm and whether it is headquartered elsewhere, enabling MNE subsidiaries to be identified, in order to explore differences between them and local firms.

\section{Hypothesis 5: MNE subsidiaries are more likely to practice share ownership schemes and use individual performance based pay than their local counterparts.}

\section{DATA AND METHODS}

\subsection{Data Collection}

We use data from the latest available 2009/2010 Cranet survey, containing evidence on human resource management and labor relations in 14 countries (Cranet, 2011) for 1,514 public and private sector firms. Following Amable (2003) and Lane (2007) we use four specific 'capitalist

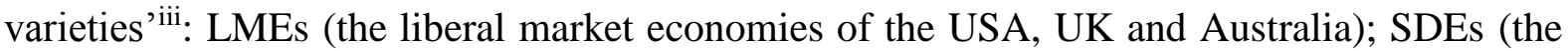


social democratic economies of Sweden, Denmark, Iceland, Norway and Finland), CMEs (Continental European Capitalist economies of Germany, the Netherlands, Belgium, Austria and Switzerland), and Japan. To compare within each variety we take the largest economy, by size, as the reference country (the USA for LMEs, Sweden for SDEs, Germany in CMEs, and Japan as a stand-alone variety). ${ }^{\text {iv }}$

The Cranet survey is designed by a multi-cultural team, translated and then back translated (Brislin, et al., 1973; Matsumoto \& van de Vijver, 2010) into the language(s) of each country. The questions are posed to the most senior HRM person in the organization and are, as far as is possible, 'factual': That is, in order to cut down on self-reporting errors and single rater bias (Gerhart, et al., 2000), potential cultural bias, and common methods bias (Podsakoff et al., 2003) they ask for presence or absence, numbers or percentages, rather than opinions that may be congeneric in quality. ${ }^{\mathrm{v}}$

Each variable, or group of variables, allows us to characterize a particular facet of organizational employment practice. In all but the largest countries the research uses a full population survey; in the larger ones it uses stratified random sampling to ensure that the organizations receiving the survey are balanced in terms of sector and (above the threshold of 100 employees) size and are broadly representative of each economy (Brewster et al., 2007). The full set of variable definitions is defined in Table 2, while Table 3 summarizes the descriptive statistics and correlations between variable. Response rates vary with country, ranging from just over $10 \%$ to nearly $40 \%$, with most countries falling towards the latter end of the spectrum - a relatively good result for full population surveys (c.f. Cooke et al. 2000).

Table 2. Variable definitions

\begin{tabular}{|c|c|c|}
\hline General Category & Specific Category & Survey Question \\
\hline Compensation & $\begin{array}{l}\text { Managers offered ownership } \\
\text { options }\end{array}$ & $\begin{array}{l}\text { Combines two questions "Do you offer any stock options to [management } \\
\text { employees]? Yes or no." and "Do you offer any employee share schemes to } \\
\text { [management employees]? Yes or no." }\end{array}$ \\
\hline
\end{tabular}


Prof/tech offered ownership options

Clerical/manual offered ownership options

Managers offered performance related pay

Prof/tech offered performance related pay

Clerical/manual offered performance related pay

Stakeholders commitments to pay bargaining

Unionisation rates

Joint consultative committee or works committee

Employer recognition of unions in collective bargaining

Firm a member of an employer's association

Research and development expenditure (\% of GDP)

\section{Country Effects}

General government final consumption expenditure (\% of GDP)

Foreign direct investment, net outflows (\% of GDP)

Year change

MNE

Firm Effects

Employees

Public
Combines two questions "Do you offer any stock options to [professional/technical employees]? Yes or no." and "Do you offer any employee share schemes to [professional/technical employees]? Yes or no."

Combines two questions "Do you offer any stock options to [clerical/manual employees]? Yes or no." and "Do you offer any employee share schemes to [clerical/manual employees]? Yes or no."

Do you offer variable pay (pay that varies at intervals, e.g.. annually/monthly/weekly) to [management employees] based on [individual performance]? Yes or no.

Do you offer variable pay (pay that varies at intervals, e.g.. annually/monthly/weekly) to [prof/tech] based on [individual performance]? Yes or no.

Do you offer variable pay (pay that varies at intervals, e.g.. annually/monthly/weekly) to [clerical/manual] based on [individual performance]? Yes or no.

What proportion of the total number of employees in your organization are members of a trade union?: $(0 ; 1-10 ; 11-25 \% ; 26-50 \% ; 51-75 \% ; 76-100 \%)$

Do you have a joint consultative committee or works council? Yes or no.

Do you recognise trade unions for the purpose of collective bargaining? Yes or no.

Is your organization a member of an employers' association? Yes or no.

Expenditures for research and development are current and capital expenditures (both public and private) on creative work undertaken systematically to increase knowledge, including knowledge of humanity, culture, and society, and the use of knowledge for new applications. R\&D covers basic research, applied research, and experimental development.

General government final consumption expenditure (formerly general government consumption) includes all government current expenditures for purchases of goods and services (including compensation of employees). It also includes most expenditures on national defence and security, but excludes government military expenditures that are part of government capital formation.

Foreign direct investment are the net inflows of investment to acquire a lasting management interest (10 per cent or more of voting stock) in an enterprise operating in an economy other than that of the investor. It is the sum of equity capital, reinvestment of earnings, other long-term capital, and short-term capital as shown in the balance of payments. This series shows net outflows of investment from the reporting economy to the rest of the world and is divided by GDP.

Percentage change in GDP per capita, PPP (constant 2005 international \$), between 2005/6 and 2008/09

MNE operating outside their country of origin are identified by matching situation where firms answer the question country identified by the question where is "Country organization based in." does not match the country where the firm is located.

Number of employees.

Public sector firm. 
Table 3. Descriptives and correlations ${ }^{\mathrm{a}}$

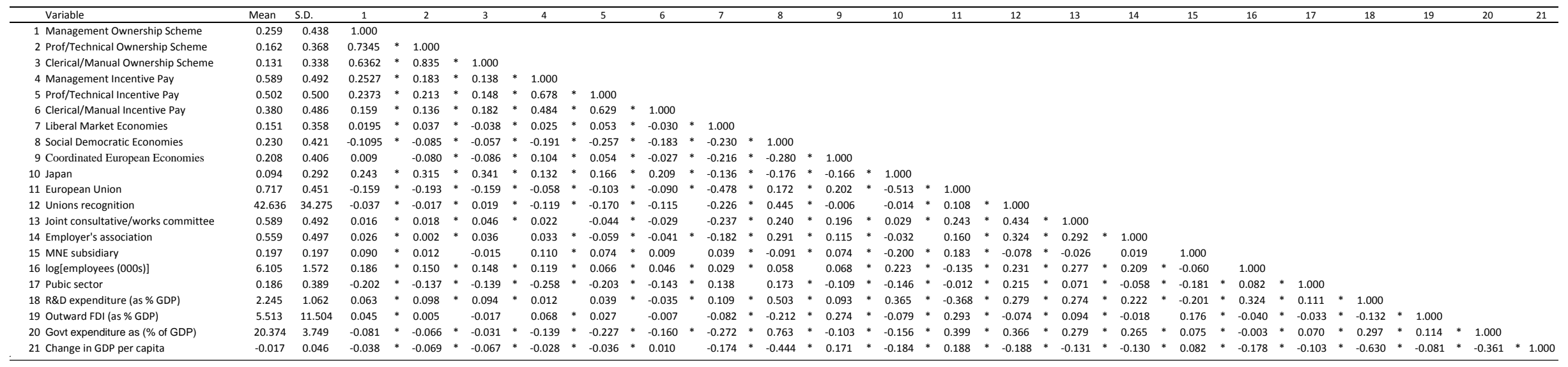

${ }^{a}$ Descriptive statistics; $\mathrm{n}=1,354$ pairwise; ${ }^{*} \mathrm{p}<0.05$. 


\subsection{Dependent variables}

In line with our hypotheses, we utilize two dependent variables: The use of share ownership schemes and the use of performance-related pay. Two questions were asked to enable us to examine the extent and depth of use of each schemes relating to employees at three distinct ranks (management; professional/ technical; and clerical/ manual employees): (i) 'Do you offer any stock options or employee share schemes to [management or professional/technical or clerical/manual employees]? Yes or No.', and (ii) 'Do you offer variable pay (pay that varies at intervals, e.g. annually/monthly/weekly) to [management or professional/technical or clerical/manual employees] based on [individual performance]? Yes or No'.

\subsection{Independent variables}

\subsubsection{Co-Determination and Contingent Pay}

It can be argued that there is as much variety within national archetypes as between them (Walker et al., 2014). Internal firm dynamics and ownership characteristics might have a stronger effect than national setting in determining the relative use of financial incentives (Kolb, 2012; Jones et al., 2012). Firms may have 'space' even within national institutional frameworks to make real strategic choices according to variations in firm characteristics (Poutsma et al., 2012: 1513). We use a series of variables to capture the extent of codetermination in work and employment relations, and the extent to which this may impact on the relative use of financial incentives. The variables cover labor institutions, such as trade unions, collective bargaining, employee initiatives works councils and joint consultative committees (JCCs), and employers via employers associations.

In many CMEs, there remains widespread use of co-determinative mechanisms impacting on the social market of work (Brewster et al., 2007; Whitley, 1999). The presence of unions, collective bargaining and works councils or joint consultative committees (JCCs) will serve to 
constrain managerial power regardless of contexts (Brewster et al., 2007). If all countries are liberalizing, the relative pace of firm reform may vary according to the countervailing power of other interests (Streeck, 2009). Strong employers' associations may deter organizations from departing from national and sectoral norms when it comes to pay setting. Hence, it could be argued that the presence or absence of trade unions and co-determinative mechanisms will impact on the nature and extent of performance based pay.

\subsubsection{Other Firm Specific Influencers}

We capture other salient firm features, such as whether the organization operates in the public or private sector (Public). We also control for size of the organization (proxied by number of employees: $(\log ($ Employee $))$.

\subsubsection{Industry, Country and Regional Effects}

In incrementally innovative manufacturing industries, firms are more likely to leverage competitive advantage through closer ties with suppliers, customers, and workers, whereas, higher tech activities and much of the service sector are characterized by adversarial competition and shorter term, more contingent, relations between the firm and its employees (Hall \& Soskice, 2001). So in addition to capturing the differing compositions of economic activity across countries we incorporate a full set of industry dummies based on the European Union, NACE, categories at the 2-digit level. ${ }^{\mathrm{vi}}$

We include country specific fixed effects to capture country differences within market economy types. The fixed effects are country specific institutional and other country specific differences that we cannot directly observe and some country specific observable attributes. We capture these country specific effects by looking at four variables. Level of innovation intensity is measured by the $\mathrm{R} \& \mathrm{D}$ expenditure, both public and private, as a percentage of GDP. National degrees of innovation intensity are seen as indicators of the focal country 
commitment to stimulate innovation. Higher degrees of R\&D would be associated with more innovation, and hence, a need to offload some of the risks onto employees. Conversely, incentive pay via ownership schemes also serves as a mechanism to lock highly skilled labor into longer-term commitment to the focal firm, as well as inhibiting knowledge transfer and protecting intellectual property. It has been argued that a defining feature of LMEs is a welldeveloped high technology sector with a commensurately greater emphasis on R\&D (Hall \& Soskice, 2001). We also include outward FDI as a percentage of GDP as an indicator of the country's openness as well as the degree of competitiveness of the national economy, and general government final consumption expenditure (\% of GDP) provides an indicator as to the extent of the public sector as public organizations are less likely to make use of such schemes (Prentice et al., 2007:13). Data for each of these indicators is collated from the World Bank. Recent work by Gooderham et al. (2015) found that one (but only one) of Hofstede's country specific cultural measures ('masculinity/ femininity') was a significant determinant of performance related pay systems (Hofstede, 2010), so we applied that as a control.

Finally, we capture the European Union as a regional grouping to account for the homogenizing effects of some labor market policies across groups. There is much debate about the impact of Europeanization, which has variously been presented as a liberalizing force, and one that has spread a common social model. Within the area of work and employment relations, the European Court of Justice has had a recent track record of focusing on upholding individual, rather than collective rights, and has made a series of rulings that have restricted the options open to unions (Dølvik \& Visser, 2009). Whilst the Europeanization process may have encompassed some attempts to promote greater social dialogue, it has been argued that in recent years these efforts have been on the retreat (Currie \& Teague, 2016; Prosser, 2011).

\subsection{Model}


We undertake a mediation analysis (general treatments of the methods are found in MacKinnon, 2008; Hayes, 2013, while two recent contributions from the International Business literature come from Villar, 2014; Fernandez-Mesa, 2015). Specifically we assume that one variable $Y$, depends on $X$ and $Z$. Furthermore, $X=F(Z, z 1)$. The impact of each variable can be expressed graphically:

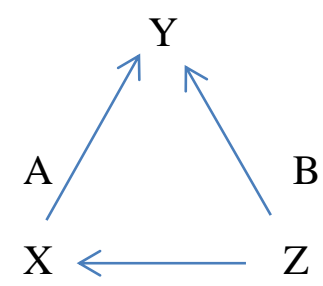

C

We can run various regressions: $Y=f(X)$ we estimate the total effect of $X$ on $Y . Y=F(Z)$ we estimate the total effect of $Z$ on $Y . Y=F(X, Z)$ we estimate the direct effect of $X$ on $Y$, once we controlled for $Z$, (arrow $A$ ), and the direct effect of $Z$ on $Y$ once we controlled for $X$ (arrow $B$ ). But, since there is a causal effect from $Z$ to $X$, for example, we would be interested in distinguishing the part of the total effect of $X$ on $Y$ that is due to the indirect effect caused by $Z$ : That is $Z$ affects $X$ that affects $Y$. In this case, we need the estimated effect of $Z$ on $X$ (arrow C).

In modeling performance incentives we need to account for both the key explanatory variable association of wage setting and institutional variables impacting upon comparative capitalisms, as well as the impact of wage setting institutions directly on those incentives. To account for these we provided a nested structure first estimating

$V o C_{k}=\beta_{0}+\sum_{j-1}^{J} \beta_{j} Z_{i}+\sum_{s-1}^{S} \beta_{s} Z_{s i}+\sum_{c-1}^{C} \beta_{c} Z_{c i}+\sum_{r-1}^{R} \beta_{r} Z_{r i}+\varepsilon_{i s c r k}$ 
Where $k$ is the comparative capitalism in which firms, $i$, operate, and where $Z$ are its determinants. These determinants are captured and operate at the firm, $i$, industrial sector, $s$, country, $c$, and regional group, $r$, levels. Doing so enables us to extract the indirect impacts of the $Z$ variables. Then we can utilize the predicted values of the comparative capitalism models in the second stage estimates:

Incentivisation $_{i}=\beta_{0}+\sum_{k-1}^{K} \beta_{k}$ VoC $_{k}+\sum_{j-1}^{J} \beta_{j} Z_{i}+\sum_{s-1}^{S} \beta_{s} Z_{s i}+\sum_{c-1}^{C} \beta_{c} Z_{c i}+\sum_{r-1}^{R} \beta_{r} Z_{r i}+\varepsilon_{i s c r k}$

Where incentivization is the set of dependent variables - the extent and depth of use of ownership schemes or incentive schemes relating to employees at three distinct ranks (management; professional/ technical and clerical/ manual employees) - and the explanatory, $X$ variables, are the direct impacts again at the firm, industry sector, country and regional grouping (EU) levels.

\section{ANALYSIS AND RESULTS}

We examine sets of results in relation to: 1 . indirect impacts of financial incentivization via comparative capitalisms; 2 . direct effects in relation to international comparative systems and MNEs. Both effects are estimated simultaneously, however we discuss them consecutively for clarity. There are minor differences in indirect estimation as there are minor differences in the number of firms who responded to questions relating to each of the different measures (with a difference in the number of observations missing between the most completed survey question, management stock option, ranging between 12 and 96 observations), however the findings are qualitatively identical. 


\subsection{Indirect Effects of Compensation Setting and Indirect Effects on Financial}

\section{Incentivization}

Table 4a examines the impact of unionization, employers' association membership, collective bargaining and works councils, as well as a set of firm, industry and country effects in shaping each capitalist variety. These are derived using logit estimations with marginal effects reported with the dependent variable being whether the firm is located in a particular capitalist variety and are generally precisely determined. ${ }^{\text {vii }}$

As prefigured in previous analyses (Amable, 2003; Hancké, et al., 2007; Whitley 1999) the findings in Table 4a underline the systematic differences between firms located in LMEs, who have lower use of coordinating labor market institutions when compared to other varieties, and the SDEs countries who are systematically higher utilizers. Firms based in CMEs are more likely to have employee works councils, consultative committees and employee associations, but less likely than the SDEs to recognize unions. Firms based in Japan also make more use of JCCs and employers' associations. So far, the results provide confidence that the data is relatively representative.

We find the presence of MNE subsidiaries is not significantly related to LMEs, SDEs and CMEs but is, negatively, related to Japan ${ }^{\text {viii }}$. Furthermore, the country specific effects proxying for innovation ( $R \& D$ intensity), efficiency of domestic investors to enter international markets (MNE outward investment/ foreign net direct investment outflows as a percentage of GDP) and public sector presence - are well determined and intuitively signed, with government sector expenditures for example being higher in the Nordic SDEs, but lower in LMEs. 
Table 4a. Factors indirectly influencing financial incentives through varieties of capitalism

\begin{tabular}{|c|c|c|c|c|c|c|c|c|c|c|c|c|c|}
\hline \multirow[b]{2}{*}{ Dependent variable } & & \multicolumn{3}{|c|}{1} & \multicolumn{3}{|c|}{2} & \multicolumn{3}{|c|}{3} & \multicolumn{3}{|c|}{4} \\
\hline & & \multicolumn{3}{|c|}{$\begin{array}{l}\text { LIBERAL MARKET } \\
\text { ECONOMIES }\end{array}$} & \multicolumn{3}{|c|}{$\begin{array}{l}\text { SOCIAL DEMOCRATIC } \\
\text { ECONOMIES }\end{array}$} & \multicolumn{3}{|c|}{$\begin{array}{c}\text { CONTINENTAL } \\
\text { MARKET ECONOMIES }\end{array}$} & \multicolumn{3}{|c|}{ JAPAN } \\
\hline & & coeff & & z-stat & coeff & & z-stat & coeff & & z-stat & coeff & & z-stat \\
\hline \multirow[t]{3}{*}{ Institutional Labour } & Unions recognition & -0.001 & $* * *$ & $(7.28)$ & 0.001 & $* * *$ & (9.93) & $4.8 \mathrm{E}-07$ & $* *$ & $(6.13)$ & $2.5 \mathrm{E}-06$ & & $(0.82)$ \\
\hline & Union recognision*Masculity & $-4.8 \mathrm{E}-05$ & $* *$ & $(2.21)$ & $-9.2 \mathrm{E}-05$ & $* * *$ & $(2.74)$ & $2.5 \mathrm{E}-07$ & $* * *$ & $(3.41)$ & $3.9 \mathrm{E}-05$ & $* * *$ & $(2.37)$ \\
\hline & Joint consultative/works committee & -0.059 & $* * *$ & $(5.28)$ & 0.010 & $*$ & $(1.96)$ & 0.064 & $* * *$ & $(8.23)$ & 0.000 & $* *$ & $(2.49)$ \\
\hline Market Institutions & Employer's association & -0.026 & $* * *$ & $(2.79)$ & 0.033 & $* * *$ & $(7.43)$ & 0.023 & $* * *$ & $(3.32)$ & 0.004 & $* * *$ & $(3.16)$ \\
\hline \multirow[t]{3}{*}{ Firm Effects } & MNE subsidiary & -0.001 & & $(0.97)$ & 0.000 & & $(0.03)$ & 0.063 & & $(1.42)$ & -0.125 & $* * *$ & $(7.71)$ \\
\hline & $\log [$ employees (000s)] & 0.005 & $* *$ & $(1.68)$ & -0.005 & $* *$ & $(4.57)$ & -0.004 & $* * *$ & $(2.15)$ & -0.004 & $* * *$ & $(3.09)$ \\
\hline & Pubic Sector & 0.086 & $* * *$ & $(5.80)$ & 0.045 & $* * *$ & $(4.29)$ & -0.022 & $* *$ & $(2.24)$ & 0.005 & $* * *$ & $(11.81)$ \\
\hline \multirow[t]{4}{*}{ Country Effects } & R\&D expenditure (as \% GDP) & 0.011 & $* *$ & $(2.51)$ & 0.009 & $* * *$ & $(4.05)$ & 0.154 & $* * *$ & $(29.84)$ & -0.014 & $* * *$ & $(7.65)$ \\
\hline & Outward FDI (as \% GDP) & 0.002 & $* * *$ & $(9.49)$ & -0.003 & $* * *$ & $(18.40)$ & 0.010 & $* * *$ & (34.85) & 0.000 & $* * *$ & $(9.28)$ \\
\hline & Govt expenditure as (\% of GDP) & -0.022 & $* * *$ & $(17.25)$ & 0.016 & $* * *$ & $(25.75)$ & -0.003 & $* * *$ & $(3.17)$ & -0.003 & $* * *$ & $(17.54)$ \\
\hline & Change in GDP per capita & -0.019 & $* * *$ & $(13.52)$ & -0.011 & $* * *$ & (15.79) & 0.036 & $* * *$ & (33.49) & -0.004 & $* * *$ & $(15.73)$ \\
\hline Country Dummies & & YES & & & YES & & & YES & & & YES & & \\
\hline Industry Dummies & & YES & & & YES & & & YES & & & YES & & \\
\hline $\mathrm{N}$ & & 1,514 & & & 1,514 & & & 1,514 & & & 1,514 & & \\
\hline Pseudo $\mathrm{R}^{2}$ & & 0.463 & & & 0.795 & & & 0.443 & & & 0.271 & & \\
\hline
\end{tabular}

${ }^{* * *} \mathrm{p}<0.01 ; * * \mathrm{p}<0.05 ;{ }^{*} \mathrm{p}<0.10$. Coefficients are marginal effects. White-corrected z-statistics in parentheses. 


\subsection{Direct Effects of Compensation Setting and Direct Effects on Financial Incentivization}

We turn to the core analysis with the results concerning the direct effect of capitalist varieties on financial incentivization being found in Table $4 \mathrm{~b}$.

First we look at the results of the differences in utilization of share ownership schemes and performance related pay between the different types of CME and how far each are from LMEs, looking at both managerial and non-managerial ranks.

In general, the results imply that the use of share schemes in LMEs, CMEs, and Japan are similar. This offers support for Hypothesis 3a, but challenges Hypothesis 1a. The only exception is that use is lower for CME's professional staff, however the finding is only weakly supported (significant at the $10 \%$ level). LMEs exhibit higher use of performance pay then other capitalist archetypes, except for Japan where the use of performance pay is similar (partially supporting Hypothesis $1 \mathrm{~b}$ and fully supporting Hypothesis $3 \mathrm{~b}$ ). Although share options were somewhat less common in CMEs than liberal markets (lending support for hypothesis $2 \mathrm{a}$ ), the differences were rather less pronounced when compared to other types of capitalism. We find that share ownership schemes are less likely to be found in SDEs than in the other types of capitalism (supporting Hypothesis 4a), and that performance pay is less common in SDEs than other types of capitalism (supporting Hypothesis $4 b$ ).

The results are already indicative. The similarity of findings across market economies may reflect the gradual dissemination of share ownership schemes in continental Europe. However, the findings also indicate that the differences between CMEs and liberal markets are more pronounced in terms of the relative utilization of performance related pay than in the use of share ownership schemes (confirming Hypothesis $2 b$ ). 
Table 4b. Direct influences on financial incentive

\begin{tabular}{|c|c|c|c|c|c|c|c|c|c|c|c|c|c|c|c|c|c|}
\hline & & 1 & & & 2 & & & 3 & & 4 & & 5 & & & 6 & & \\
\hline \multirow[t]{2}{*}{ Dependent variable } & & \multicolumn{3}{|c|}{$\begin{array}{l}\text { MANAGEMENT } \\
\text { OWNERSHIP SCHEME }\end{array}$} & \multicolumn{3}{|c|}{$\begin{array}{l}\text { PROF/TECH } \\
\text { OWNERSHIP SCHEME }\end{array}$} & \multicolumn{2}{|c|}{$\begin{array}{l}\text { CLERICAL/MANUAL } \\
\text { OWNERSHIP SCHEME }\end{array}$} & \multicolumn{2}{|c|}{$\begin{array}{l}\text { MANAGEMENT } \\
\text { PEFORMANCE PAY }\end{array}$} & \multicolumn{3}{|c|}{$\begin{array}{l}\text { PROF/TECH } \\
\text { PEFORMANCE PAY }\end{array}$} & \multicolumn{3}{|c|}{$\begin{array}{l}\text { CLERICAL/MANUAL } \\
\text { PEFORMANCE PAY }\end{array}$} \\
\hline & & coeff & & z-stat & coeff & & z-stat & coeff & z-stat & coeff & z-stat & coeff & & z-stat & coeff & & z-stat \\
\hline CAPITALISMS & SOCIAL DEMOCRATIC ECONOMIES & -0.256 & ** & $(2.50)$ & -0.353 & $* * *$ & (3.75) & -0.301 & *** $\quad(4.02)$ & -0.366 & *** (3.45) & -0.444 & $* * *$ & (3.79) & -0.507 & *** ( & (4.48) \\
\hline (ref. Liberal Market & CONTINENTAL MARKET ECONOMIES & -0.098 & & $(1.07)$ & -0.163 & $*$ & (1.93) & -0.037 & $(0.55)$ & -0.221 & ** (2.27) & -0.338 & $* *$ & (3.23) & -0.228 & ** ( & (2.28) \\
\hline Economies) & JAPAN & 0.184 & & $(1.02)$ & 0.007 & & $(0.04)$ & -0.016 & $(0.14)$ & -0.053 & $(0.29)$ & -0.125 & & $(0.66)$ & 0.209 & & (1.21) \\
\hline \multirow[t]{3}{*}{ Firm Effects } & MNE subsiduary & 0.196 & ${ }^{* * *}$ & $(5.25)$ & 0.053 & ** & $(2.08)$ & 0.058 & ** $\quad(2.11)$ & 0.067 & ** (1.98) & 0.105 & $* * *$ & $(2.84)$ & 0.104 & *** ( & (2.67) \\
\hline & log[employees (000s)] & 0.068 & *** & $(4.67)$ & 0.030 & ** & $(2.21)$ & 0.022 & ** $\quad(2.30)$ & 0.028 & ** (2.11) & 0.034 & $* *$ & $(2.37)$ & -0.003 & & $(0.22)$ \\
\hline & Pubic sector & 0.103 & $*$ & $(1.72)$ & -0.050 & & $(1.00)$ & -0.056 & (1.44) & -0.130 & ** $(2.08)$ & -0.164 & $* * *$ & $(2.57)$ & -0.029 & & $(0.46)$ \\
\hline Institutional Labour & Joint consultative/works committee & -0.001 & & $(1.21)$ & $3.8 \mathrm{E}-04$ & & $(0.88)$ & $3.7 \mathrm{E}-04$ & $(1.03)$ & $-7.7 \mathrm{E}-05$ & $(0.15)$ & $-1.9 \mathrm{E}-04$ & & $(0.33)$ & 0.001 & & $(0.93)$ \\
\hline \multirow[t]{3}{*}{ Market Institutions } & Employer's association & 0.039 & & $(1.12)$ & 0.027 & & $(0.86)$ & 0.039 & ${ }^{*} \quad(1.72)$ & 0.031 & $(0.92)$ & 0.003 & & $(0.08)$ & 0.036 & & (1.03) \\
\hline & Unions recognition & 0.023 & & $(0.62)$ & 0.056 & ** & (1.96) & 0.058 & ** $\quad(2.55)$ & 0.075 & ${ }^{*} \quad(1.92)$ & 0.039 & & $(0.93)$ & 0.046 & & (1.13) \\
\hline & Union recognisionMasculity & $3.6 \mathrm{E}-05$ & & $(0.16)$ & $-4.9 \mathrm{E}-04$ & & $(1.32)$ & 0.001 & $(0.58)$ & $1.7 \mathrm{E}-05$ & $(0.72)$ & $5.5 \mathrm{E}-05$ & & $(0.19)$ & $3.5 \mathrm{E}-05$ & & $(0.57)$ \\
\hline Regional Cluster & European Union & -0.227 & ${ }^{* *}$ & (6.59) & -0.239 & ${ }^{* * *}$ & $(8.27)$ & -0.193 & *** (7.79) & -0.023 & $(0.62)$ & -0.007 & & $(0.18)$ & -0.071 & ${ }^{*} 1$ & (1.85) \\
\hline \multirow[t]{4}{*}{ Country Effects } & R\&D expenditure (as \% GDP) & 0.084 & * & (1.92) & 0.083 & ** & (2.31) & 0.128 & $* * * \quad(4.17)$ & 0.042 & $(0.88)$ & 0.138 & $* * *$ & (2.49) & 0.237 & *** ( & (4.33) \\
\hline & Outward FDI (as \% GDP) & 0.006 & ${ }^{* * *}$ & $(2.87)$ & 0.003 & ** & $(2.22)$ & 0.000 & $(0.01)$ & 0.004 & $* * *(3.20)$ & 0.004 & * & (1.68) & 0.002 & & $(0.96)$ \\
\hline & Govt expenditure as (\% of GDP) & -0.022 & ${ }^{* *}$ & (2.27) & -0.032 & $* * *$ & (3.78) & -0.027 & $* * * \quad(4.72)$ & -0.006 & $(0.62)$ & -0.008 & & $(0.86)$ & 0.017 & & (1.62) \\
\hline & Change in GDP per capita & 0.001 & & $(0.90)$ & 0.005 & & $(0.90)$ & -0.956 & ${ }^{*} \quad(1.67)$ & -0.962 & (1.30) & -0.002 & & $(0.76)$ & -0.748 & & (1.01) \\
\hline Country Dummies & & YES & & & YES & & & YES & & YES & & YES & & & YES & & \\
\hline Industry Dummies & & YES & & & YES & & & YES & & YES & & YES & & & YES & & \\
\hline $\mathrm{N}$ & & 1,514 & & & 1,449 & & & 1,502 & & 1,418 & & 1,354 & & & 1,388 & & \\
\hline Log pseudo likelihood & & -764 & & & -633 & & & -542 & & -874 & & -893 & & & -915 & & \\
\hline Pseudo $\mathrm{R}^{2}$ & & 0.210 & & & 0.197 & & & 0.214 & & 0.139 & & 0.139 & & & 0.109 & & \\
\hline
\end{tabular}

$* * * \mathrm{p}<0.01 ; * * \mathrm{p}<0.05 ; * \mathrm{p}<0.10$. Coefficients are marginal effects. White-corrected $\mathrm{z}$-statistics in parentheses. 
MNE subsidiaries are different: They use share ownership schemes at managerial level one fifth more often than local firms, with ownership schemes being provided at lesser rates for staff at lower ranks in the organization. Performance pay is as commonly used for professional and technical staff in MNE subsidiaries as it is for management. The influence of MNEs may go some way to explaining the spread of such schemes in the CMEs. Overall, both, shared ownership schemes and performance related pay are more likely to be found in MNEs than in their local counterparts, supporting Hypothesis 5.

Turning to the control variables, unsurprisingly, for managers there is no evidence that higher institutional coordination through employees (trade unions, works councils or JCCs) or employers' associations directly impacts upon share schemes. Table $4 \mathrm{a}$ implies that those institutions influence stock option incentives only indirectly via capitalist varieties with these effects reinforcing the already lower rates of utilization of share schemes in Nordic SDEs. However, there is evidence that higher unionization rates and greater participation in employers' associations increase firm's provision of share schemes to lower ranks.

Lower rates of share ownership are associated with membership of the European Union, consistent with the 'triad' regionalist view (Arregle, et al, 2009; Rugman \& Verbeke, 2004). However we find no evidence that EU membership impacts upon performance pay, confirming the limited mediating effects of Europeanization (Prosser, 2011). Furthermore, larger firms are more likely to use either stock options or performance pay at managerial and professional/ technical level but not at the lower level, reflecting a bias towards more closely encouraging senior ranks towards a shareholder value agenda. Industry fixed-effects are jointly significant (with F-statistics of 100 or more across estimations), as are the country fixed effects.

Turning to the country level controls, countries that have greater R\&D intensity as a proportion of GDP have higher share option utilization across all ranks as well as more performance pay 
at lower ranks, perhaps indicating that nations with higher technology intensive industries see it as appropriate to incentivize their managers via share options rather than via performance pay. As expected, higher amounts of government expenditure as a proportion of GDP reduce the extent of financial incentives.

\section{DISCUSSION}

Our study confirms that context has a significant effect on the relative utilization of share ownership schemes and individual performance related pay. We also confirmed that it is unhelpful to consider CMEs as a single coherent category: Rather it comprises a number of distinct archetypes, each with characteristics of their own. More specifically, we found clear, firm-level evidence that both share schemes and performance related pay are more likely to be found in LMEs in comparison to the Nordic SDEs. It can be argued that SDEs are the CMEs that have been most resistant to liberalization, and retain the strongest collectivist elements (Goergen et al., 2009): This would explain the limited headway such forms of contingent pay have made in such settings. It can be argued that, as such countries have relatively high tax rates, non-pay elements of executive reward will assume greater importance (De Silva, 2016). In contrast, in Germany, in an effort to retain jobs, there has been a spread of concession bargaining, centering on flexibility in working time and in the allocation of rewards and how this is linked to organizational performance (Doellgast \& Grier, 2017). This does not mean that the German system per se is eroding; rather, it can be argued that it has been reinforced in other areas, most notably through the vitality of the industrial vocational training system (Thelen, 2014).

Such distinctions are less visible within other CMEs. In particular, share schemes were more common in Japan, which is commonly seen as a CME. Share ownership schemes there across both the managerial and professional levels of the organization were as common as in LMEs, 
though not so at lower organizational levels. However, more secure employment means that share ownership schemes are less a mechanism for compensating workers for job insecurity, and more a means of binding employer and employee together in the long term.

As noted above, share ownership schemes serve somewhat different purposes when aimed at rank and file or at managers. For clerical and manual workers the purposes would encompass risk sharing and may be intended to make more palatable a focus on share price maximization rather than other organizational priorities. For managers such incentives are aimed at solving presumed agency problems. Of course, these different rationales are mutually compatible, and reflect a common systemic orientation towards prioritizing short-term shareholder value.

The findings regarding Japan confirm the predictions of Calmfors and Driffill (1988) that the country represents an example of decentralized wage setting, sharing common features with LMEs in this regard. Individual performance based pay has never been prohibited by law, although share ownership schemes were restricted. Recent accounts highlight the extent to which the Japanese system has liberalized in recent years, with knock-on effects on reward systems (Sako \& Kotosaka, 2012). However, it can be argued that whilst Japan is certainly becoming more diverse in terms of pay and reward systems, the importance of seniority in wage setting persists: While contingent reward systems have spread, their effects have been 'modest' (Jackson \& Moerke, 2005; Keizer, 2011). This means that employees have a strong incentive to remain with firms - reinforcing the traditional lifetime employment model amongst larger organizations - and ensures that even individually orientated pay setting retains a strong collective flavor. So employees are more likely to retain shares they have been allocated, in contrast to LMEs, where they often serve the purpose of a type of emergency saving to be cashed in in the event of redundancy. 
Does this mean that contemporary Japan has more in common with LMEs than other CMEs (c.f. Hall \& Soskice, 2001)? Recent comparative institutionalist work has highlighted the extent to which each national system is internally diverse, combining seemingly contradictory features, but in such a manner as to still retain its broad character (Wood \& Lane, 2012). In other words, institutions are never perfectly aligned, and this will make for seemingly contradictory rules, conventions, and associated sets of practices co-existing. Indeed, 'unexpected' practices, at odds with the general systemic norm, may impart a necessary degree of flexibility, compensating for distortions generated elsewhere in the system (Crouch, 2005). Actually, we also found that firms based in Japan made significantly more use of Joint Consultative Committees and employers' associations than their LME counterparts. Other work has suggested close similarities between Japan and the CME ideal type in a range of other areas, such as the relative density of inter-firm and stakeholder ties, high levels of employment security, and the centrality of incremental innovation (Dore, 2000; Thelen and Kume, 2006). Hence, we can conclude that, whilst undeniably a CME, Japan has some similarities with LMEs when it comes to pay setting. The coexistence of very different practices over a sustained period of time without undermining the overall operation of a CME would suggest that national capitalist archetypes can accommodate a fair degree of difference in core systemic features: This, in turn, might suggest that reforms to coordinated markets in a single area may have only limited effects in others.

\section{CONCLUSION}

This study differs from earlier comparative work using the Cranet data in its inclusion of Japan, its core focus on differences within the Coordinated Market Economies category and its examination of the position of MNEs. In contrast, earlier work concentrated on differences in pay systems between Liberal and European Coordinated Market Economies, the characteristics 
of rewards in other institutional frameworks, and the relative centralization of bargaining (Pendleton et al. 2003; 2001; Poutsma \& De Nijs 2003; Brewster et al. 2013; Croucher et al. 2010; Kalmi et al. 2012). At the same time, our study highlights some continuities with the findings of the earlier work. This includes persistent differences between the practices encountered in LMEs and other types of capitalism - pressures to convergence notwithstanding (Streeck, 2009). This confirms that institutional arrangements are deeply embedded, and not easily derailed even if structural changes in the global capitalist ecosystem take place. It would also suggest that it is possible for quite deregulated practices in some areas to co-exist with relatively high levels of coordination in other areas (Walker et al., 2014).

Whilst it has been argued that the Continental-European Market Economies have moved towards greater use of share schemes in the last decade or so (Kalmi et al., 2012), such schemes are still used less and have not diffused to lower levels of organizations. The use of share ownership schemes and performance based pay is even less common in the Nordic Social Democratic Economies. These findings confirm the strength of collectivist institutions in the SDEs, and the differences between them and Continental Europe. This would suggest that the manner in which shareholder rights are mediated in CMEs varies according to specific institutional features: Institutions are not similarly aligned across CMEs. While it is certainly possible to unpick what variations in rules (e.g. centralization of bargaining, worker rights) may determine differences in practice, and hence, discard national institutional archetypes altogether, doing so would discount the importance of unwritten conventions and norms of acceptable behavior in determining differences within national settings. We must be careful not to make assumptions: Japan is closer to LMEs than other CMEs when it comes to the utilization of share ownership schemes, although these effects are mediated by much higher levels of job security, providing workers with stronger incentives to retain the shares they have been allocated into the long term. Complex assemblies of institutions have close and direct 
effects on specific organizational practices, and similarity between countries in one area does not make for similarities in others (Amable, 2003). In most other respects - ranging from employment security to codetermination to a strong commitment to the development of firm and industry specific human capital - Japan is clearly a CME (Thelen and Kume, 2006). What this study highlights is that institutional features do not need to be closely coordinated and mutually supportive for a national model to persist: Indeed, an ability to accommodate seemingly very different sets of firm level practices might be considered to be not only an indicator of internal systemic flexibility, but also one of strength.

MNE subsidiaries are more likely to use share schemes and performance related pay than their indigenous counterparts. It is indeed possible that MNEs may serve as 'norm entrepreneurs', pioneering and disseminating new practices (Dore, 2008; Sako \& Kotosaka, 2012). On the one hand, the differences are relatively small and not always significant. They are most pronounced at managerial level, which is likely to mold managerial choices and strategies. This adds credence to the view that MNEs are less rooted in individual national institutional environments and more able to innovate (Morgan, 2012; Dunning, 1981). However, especially when it came to categories of employee other than managers, the differences with local businesses are not large. Perhaps common practices within specific national settings make for a greater predictability, lowering transaction costs in dealing with middle and lower ranking staff (Marsden, 1999). Following local norms will also be a simple way to generate the legitimacy that such foreign organizations need (Dowling \& Pfeffer, 1975; Kostova, Roth \& Dacin, 2008; Kostova \& Zaheer, 1999).

A new feature in this research, the use of country level controls, confirms that, for example, R\&D and government influence may appear to be related to particular comparative capitalisms but are not directly related to incentivization. Even here, however there are some findings that 
challenge the accepted wisdom. Neither share schemes nor performance related pay are more common in workplaces with collective bargaining, works councils and JCCs (Kato \& Morishima, 2002; Ichniowski, et al., 1997): There is no direct effect. What we did find is that these institutions are strongly associated with different versions of comparative capitalisms and that the influence on incentivized pay systems operates indirectly at this level.

At a theoretical level, the study confirms variation within CMEs, opening the question as to whether LMEs might be similarly diverse. This constitutes fertile ground for future research.

Our study highlights the extent to which key features of reward system continue to vary according to setting, and whether an organization is multinational or not. MNEs are more likely to use share options, but mainly for higher job bands. Despite predictions of general liberalization, it is evident that Continental-European capitalism, and above all, the SDEs retain their distinctive features, including a weaker emphasis on performance related pay and share ownership schemes for both senior managers and rank-and-file. Finally, although MNEs are clearly different in that they are more likely to promote individual performance related pay and share ownership schemes irrespective of setting - reflecting, perhaps, the global ecosystemic dominance of the LME model and associated firm level practices - these differences were not always strong, especially when it came to non-managers. In other words, whilst MNEs are less 'tied' to particular national ways of doing things, and may be more likely to pioneer new practices, the extent of such innovation remains constrained by local institutional realities.

\subsection{Limitations and Scope for Future Research}

Like all research, this has limitations. Our evidence is drawn from organization with more than 100 employees, which is a minority in most countries, and covers only a limited number of countries. This reduces the generalizability of the findings. Our data examine the practice of MNE subsidiaries rather than the policy of Headquarters. And whilst it covers the main 
methods of incentivization considered in the literature there are other forms it does not cover and which may yield different results. Overall, however, the results here are rather robust and stand up to further examination.

There are two key areas where further research would be beneficial. First, our data comes from the senior HRM specialists managing incentivization but we have no views from the managers and employees themselves about the implications of such practices or their attitudes towards them. Second, this study has been cross-sectional and there is a need for more longitudinal research. Looking back at earlier waves of Cranet we see strong path dependence, although more systematic analysis of changes over time, especially within the Coordinated Market Economies category, would add more nuanced insights. Interestingly, much of the literature on comparative capitalisms has tended to focus on variations in areas such as tenure and skills, rather than on differences in firm level reward systems (Amable 2003; Hall \& Soskice 2001). Whilst this paper goes some way to redressing this lacuna, it also raises further questions as to what really distinguishes firm practices in differing national contexts, and the extent to which seemingly contradictory practices may compensate for, or even reinforce, each other. These gaps can be filled by further empirical research at the firm level and we look forward to such developments.

\section{ACKNOWLEDGEMENTS}

We are grateful to colleagues in the Cranet research network who collected the data and discussed these topics with us and to Cranfield School of Management that administers the network. 


\section{REFERENCES}

Ahlvika, C. \& Björkman, I. (2015). Towards explaining subsidiary implementation, integration, and internalization of MNC headquarters HRM practices, International Business Review, 24, 3, $497-505$.

Amable, B. (2003). The diversity of modern capitalism. Oxford: Oxford University Press.

Aoki, M. (2010). Corporations in evolving diversity. Oxford: Oxford University Press.

Arregle, J. L., Beamish, P. W., \& Hebert, L. (2009). The regional dimension of MNEs' foreign subsidiary localization. Journal of International Business Studies 40, 86-107.

Ataullah, A., Davidson, I., Le, H. \& Wood, G. (2014), Corporate Diversification, Information Asymmetry and Insider Trading. British Journal of Management, 25. 2, 228-251.

Aumayr, C., Welz, C., \& Demetriades, S. (2009). Performance-Related Pay and Employment Relations in European Countries. Dublin: European Foundation for the Improvement of Living and Working Conditions.

Bender, R. (2004). Why Do Companies Use Performance-Related Pay for Their Executive Directors? Corporate Governance: An International Review, 12(4), 521-533.

Botero, J., Djankov, S., La Porta, R., Lopez-de-Silanes, S., \& Shleifer, A. (2004). The regulation of labor. Quarterly Journal of Economics, 119, 1339-1382.

Brewster, C., Wood, G., Croucher, C., \& Brookes, M., (2007) Are Works Councils and Joint Consultative Committees a Threat to Trade Unions? A Comparative Analysis, Economic and Industrial Democracy. 28, 53-81. 
Brewster, C., Demirbag, M., Li, H., \& Wood, G. (2013). Management Compensation in MNCs: Cross-National Empirical Evidence, Management International Review, 53, 741-762.

Brislin, R.W., Lonner, W.J., \& R.M. Thorndike (1973). Cross-cultural Research Methods. Wiley-Interscience: London.

Calmfors, L., \& Driffill, J. (1988). Bargaining structure, corporatism and macroeconomic Performance, Economic Policy 6, 3-61.

Casper, S., Lehrer, M., \& Soskice, D. (2009). Can high technology firms prosper in Germany?' in Hancke, B., Debating Varieties of Capitalism. Oxford: Oxford University Press.

Chizema, A. \& Buck, T. (2006). Neo-institutional theory and institutional change: Towards empirical tests on the "Americanization" of German executive pay, International Business Review, 15, 5, 488-504.

Coffee, J. (2005). A Theory of corporate scandals: Why the USA and Europe differ. Oxford Review of Economic Policy, 21, 198-211.

Cook, C., Heath, F., \& Thompson, R. L. (2000). A meta-analysis of response rates in web-or internet-based surveys. Educational and Psychological Measurement, 60, 6, 821-836.

Cote, J. A., \& Buckley, R. (1987). Estimating trait, method, and error variance: Generalizing across 70 construct validation studies. Journal of Marketing Research, 24, 315-318.

Cranet (2011). Cranet Survey on Comparative Human Resource Management: International Executive Report 2011. Cranfield, Cranfield University.

Crouch, C. (2005). Capitalist diversity and change. Oxford: Oxford University Press. 
Croucher, R., Wood, G., Brewster, C., \& Brookes, M. (2012). Employee turnover, HRM and institutional contexts. Economic and Industrial Democracy, 33, 605-20.

Croucher, R., Brookes, M., Wood, G., and Brewster, C. (2010). Context, Strategy and Financial Participation: A Comparative Analysis. Human Relations, 63: 835 - 855.

Currie, D., \& Teague, P. (2016). How does European integration influence employment relations? In M. Dickmann, C. Brewster, \& P. Sparrow (Eds.), International Human Resource Management: contemporary issues in Europe (3 ed., pp. 21-48). London: Routledge.

D'Art, D. \& Turner, T. (2004). Profit sharing, firm performance and union influence in selected European countries. Personnel Review, 33, 335-350.

De Silva, S. (2016). An Introduction to Performance and Skill-Based Pay Systems. Geneva: ILO.

Doellgast, V. \& Greer, I., (2007). Vertical Disintegration and the Disorganization of German Industrial Relations. British Journal of Industrial Relations, 45(1), 55-76.

Dølvik, J. E., \& Visser, J. (2009), Free movement, equal treatment and workers' rights: can the European Union solve its trilemma of fundamental principles? Industrial Relations Journal, 40, 491-509.

Dore, R. (2008). Best practice winning out? Socio-Economic Review 6, 779-784.

Dore R (2000) Stock Market Capitalism: Welfare Capitalism, Cambridge: Cambridge University Press. 
Dörrenbächer, C., \& Geppert, M. (2011). Introduction. In Dörrenbächer, C. \& Geppert, M. (eds.), Politics and Power in Multinational Corporations. Cambridge: Cambridge University Press.

Dowling, J., \& Pfeffer, J. (1975). Organizational legitimacy: social values and organizational behavior. Pacific Sociological Review, 18, 122-136.

Driffill, J. (2006). The centralization of wage bargaining revisited: What have we learned? Journal of Common Market Studies 44, 731-756.

Dunning, J. H. (1981). The eclectic theory of the MNC. London: Allen and Unwin Fernandez-Meza, A. \& Alegre, J. (2015), Entrepreneurial orientation and export intensity: Examining the interplay of organizational learning and innovation. International Business Review, 24, 148-156.

Festing, M., Eagle, A., Dowling, P., \& Sahakiants, I. (2012). HRM activities: Pay and rewards. In Brewster, C. \& Mayrhofer, W. (Eds.), Handbook of Research on Comparative Human Resource Management. Cheltenham: Elgar.

Folkman, P., Froud, J., Johal, S., \& Williams, K. (2007). Working for themselves: Financial intermediaries and present day capitalism. Business History, 49, 552-572.

Franke, G., \& Richey, G. (2011). Improving generalizations from multi-country comparisons in business research. Journal of International Business Studies, 41, 1275-1293.

Geppert, M., Dörrenbächer, C., Gammelgaard, J. \& Taplin, I. (2013), Managerial Risk-taking in International Acquisitions in the Brewery Industry: Institutional and Ownership Influences Compared. British Journal of Management, 24, 4, 316-332. 
Gerhart, B., Wright, P.M., G.C. McMahan., \& S.A. Snell. (2000). Measurement error in research on human resources and firm performance: How much error is there and how does it influence effect size estimates? Personnel Psychology, 53, 803-834.

Goergen, M., Brewster, C., Wood, G.T., \& Wilkinson, A. (2012). Varieties of capitalism and investments in human capital. Industrial Relations 51, 501-527.

Goergen, M., Brewster, C., \& Wood, G. (2009). Corporate Governance Regimes and Employment Relations in Europe, Industrial Relations/Relations Industrielles, 64, 620-640.

Gooderham, P., Fenton-O’Creavy, M., Croucher, R. \& Brookes, M. (2015). A Multi-Level Analysis of the Use of Individual Pay-for-Performance Systems, Journal of Management. doi: 10.1177/0149206315610634. Early Online at:

http://jom.sagepub.com/content/early/2015/11/25/0149206315610634.full

Gunnigle, P., Turner, T., \& d'Art, D. (1998). Counterpoising Collectivism: Performance-related Pay and Industrial Relations in Greenfield Sites. British Journal of Industrial Relations, 36, 565579.

Hall, P., \& Soskice, D. (2001). An Introduction to the varieties of capitalism. In P. Hall \& D. Soskice (Eds.), Varieties of capitalism: The institutional basis of competitive advantage. Oxford: Oxford University Press.

Hall, P., \& Thelen, K. (2009). Institutional Change in varieties of capitalism. In Hancke, B. (Ed.), Debating varieties of capitalism. Oxford: Oxford University Press.

Hancké, B., Rhodes, M., \& Thatcher M. (2007). Introduction: Beyond Varieties of Capitalism. In Hancke, B., Rhodes, M., \& Thatcher M. (Eds). Beyond varieties of capitalism: 
conflict, contradictions and complementarities in the European economy. Oxford: Oxford University Press.

Hofstede, G., Hofstede, G.J. \& Mincov, M. (2010), Cultures and organizations: Softwares of the mind (rev. $3^{\text {rd }}$ ed.), New York: McGraw-Hill.

Hayes, A. F. (2013). Introduction to mediation, moderation, and conditional process analysis: A regression-based approach. New York: Guilford Press.

Hyman, R. (1989). The political economy of industrial relations. London: Sage.

Iacobucci, D. (2008). Mediation analysis. Thousand Oaks, CA: Sage.

Ichniowski, C., Shaw, K., \& Prennushi, G. (1997). The effects of human resource management practices on productivity: A study of steel finishing lines. American Economic Review 87, 291313.

Jackson, G., \& Deeg, R. (2008). Comparing capitalisms: Understanding institutional diversity and its implications for international business. Journal of International Business Studies, 39, $540-61$.

Jackson, G. \& Moerke, A., (2005). Continuity and change in corporate governance: comparing Germany and Japan. Corporate Governance: An International Review, 13(3), $351-361$.

Jones, D. C., Kalmi, P., Kato, T., \& Mäkinen, M. (2012). Financial participation in Finland: incidence and determinants. International Journal of Human Resource Management, 23, $1570-1589$. 
Kalmi, P., Pendleton, A., \& Poutsma, E. (2012). Bargaining regimes, variable pay and financial participation: some survey evidence on pay determination. International Journal of Human Resource Management, 23, 1643-1659.

Kato, H., \& Morishima, M. (2002). The Productivity Effects of Participatory Employment Practices. Industrial Relations Journal, 41, 487-520.

Kato, H., Lemmon, M., Luo, M., \& Schulheim, J. (2005). An empirical examination of the costs and benefits of executive stock options: Evidence from Japan. Journal of Financial Economics, 78, 435-61.

Keizer, A.B., (2011). Flexibility in Japanese internal labour markets: The introduction of performance-related pay. Asia Pacific Journal of Management, 28(3), 573-594.

Kerrin, M., \& Oliver, N. (2002). Collective and individual improvement activities: The role of reward systems. Personnel Review, 31, 320-337.

Kolb, R. (2012). Too much is not enough: Incentives in executive compensation. New York: Oxford University Press.

Kostova, T., Roth, K., \& Dacin, M. T. (2008). Institutional theory in the study of multinational corporations: A critique and new directions. Academy of Management Review, 33, 994-1006.

Kostova, T., \& Zaheer, S. (1999). Organizational legitimacy under conditions of complexity: The case of the multinational enterprise. Academy of Management Review, 24, 64-81.

Kraft, K., \& Ugarković, M. (2006). Profit sharing and the financial performance of firms: Evidence from Germany. Economics Letters, 92(3), 333-338. 
Kurdelbusch, A. (2002). Multinationals and the rise of variable pay in Germany. European Journal of Industrial Relations, 8(3), 325-349.

Lane, D. (2007). Post state socialism: A diversity of capitalisms? In Lane, D. \& Myant, M. (Eds). Varieties of Capitalism in Post Communist Countries. 13-39 London: Palgrave.

Lane, C. \& Wood, G. (2014). Capitalist Diversity: Work and Employment Relations, Wilkinson, A., Wood, G. \& Deeg, R. (eds.), Oxford Handbook of Employment Relations: Comparative Employment Systems. Oxford: Oxford University Press.

Lavelle, J., Turner, T., Gunnigle, P., \& McDonnell, A. (2012). The determinants of financial participation schemes within multinational companies in Ireland. International Journal of Human Resource Management, 23, 1590-1610.

Lee, H.-J., Iijima, Y., \& Reade, C. (2011). Employee preference for performance-related pay: predictors and consequences for organizational citizenship behaviour in a Japanese firm. International Journal of Human Resource Management, 22, 2086-2109.

Malcolm, J. D. (2013). Financial Globalisation and the Opening of the Japanese Economy. Abingdon: Routledge Curzon.

Marsden, D. (1999). A theory of employment systems. Oxford: Oxford University Press. Matsumoto, D., \& van de Vijver, F. J. R. (2010). Cross-Cultural Research Methods in Psychology. Cambridge: Cambridge University Press.

MacKinnon, D. P. (2008). Introduction to statistical mediation analysis. New York: Erlbaum. Morgan, G. (2012). International business, MNCs and national systems. In Demirbag, M., \& Wood, G. (Eds), Handbook of Institutions and International Business. Cheltenham: Elgar. 
Morgan, G. (2001). The multinational firm: Organizing across institutional and national divides. In Morgan, G., Kristensen, P-H., \& Whitley, R. (Eds.), The multinational firm: Organizing across institutional and national divides. Oxford: Oxford University Press. Morgan, G., \& Whitley, R. (Eds.). (2012). Capitalisms and capitalism in the twenty-first century. Oxford: Oxford University Press.

Morris, M., Schindehutte, M., \& Allen, J. (2005). The entrepreneur's business model: Toward a unified perspective. Journal of Business Research, 58: 726-35.

Oliver, C., (1991). Strategic responses to institutional processes. Academy of Management Review, 16(1), 145-179.

Pearl, J. (2010). An introduction to causal inference. International Journal of Biostatistics, 6 , $1-59$.

Pendleton, A., Poutsma, E., Brewster, C., \& van Ommeren, J. (2001). Employee share ownership and profit sharing in the European Union. Dublin: European Foundation for the Improvement of Living and Working Conditions.

Pendleton, A, Poutsma, E, van Ommeren, J., \& Brewster, C. (2003). The incidence and determinants of employee share ownership and profit sharing in Europe. In Kato, T. \& Pliskin, J. (Eds), The determinants of the incidence and effects of participatory organizations. Advances in the economic analysis of participatory and labor management, Volume 7, JAI Press, Greenwich, CT.

Podsakoff, P. M., MacKenzie, S. B., Jeong-Yeon, L., \& Podsakoff, N. P. (2003). Common method biases in behavioral research: A critical review of the literature and recommended remedies. Journal of Applied Psychology, 88, 879-903. 
Poutsma, E., Blasi, J. R., \& Kruse, D. L. (2012). Employee share ownership and profit sharing in different institutional contexts. International Journal of Human Resource Management, 23, 1513-1518.

Poutsma, E., \& de Nijs, W. (2003). Broad based employee financial participation in Europe. International Journal of Human Resource Management, 14, 863-892.

Prentice, G., Burgess, S. \& Propper, C. (2007) Performance-pay in the Public Sector: a review of the issues and evidence, Office of Manpower Economics, http://webarchive.nationalarchives.gov.uk/20130106083031/http://www.ome.uk.com/ downloads/Performance\%20pay\%20in\%20the\%20Public\%20Sector.\%20A\%20revie w\%20of\%20the $\% 20$ issues $\% 20$ and $\% 20$ evidence.pdf

Prosser, T., (2011). The implementation of the telework and work-related stress agreements: European social dialogue through 'soft' law? European Journal of Industrial Relations, 17(3), $245-260$.

Rugman, A. M., \& Verbeke, A. (2004). A perspective on regional and global strategies of multinational enterprises. Journal of International Business Studies, 35, 3-18.

Sako, M., \& Kotosaka, M. (2012). Institutional change and organizational diversity in Japan. In Lane, C. \& G. Wood (Eds), Institutions, internal diversity and change. London: Routledge. Streeck, W. (2009). Reforming capitalism: institutional change in the German political economy. Oxford: Oxford University Press.

Suzuki, H., \& Kubo, K. (2011). Employment Relations in Japan. In Bamber, G., Lansbury, R. \& Wailes, N., International and comparative employment relations. London: Sage. 
Thelen, K. (2014). Varieties of liberalization and the new politics of social solidarity. Cambridge: Cambridge University Press.

Thelen, K. and Kume, I., (2006). Coordination as a political problem in coordinated market economies. Governance, 19(1), 11-42.

Thompson, P., \& Vincent, S. (2010). Labor Process Theory and Critical Realism. In Thompson, P. \& Smith, C. (Eds.), Working life: renewing labor process analysis. London: Palgrave.

Villar, C., Alegre, J. \& Pla-Barber, J. (2014). Exploring the role of knowledge management practices on exports: A dynamic capabilities view, International Business Review, 23, 38-44.

Walker, J., Brewster, C. \& Wood, G. (2014). Diversity Between and Within Varieties of Capitalism, Industrial and Corporate Change, 23, 493-533.

Whitley, R. (1999). Divergent capitalisms. Oxford: Oxford University Press.

Whitley, R. (2001). How and why are international firms differ. In Morgan, G., Kristensen, P-H., \& Whitley, R. (Eds.), The multinational firm: Organizing across institutional and national divides. Oxford: Oxford University Press.

Whitley, R. (2007). Business systems and organizational capabilities. Oxford: Oxford University Press. Williams, C., \& Lee, S. (2011). Political heterarchy and dispersed entrepreneurship within the MNC, Journal of Management Studies, 48, 1243-1268.

Whitley, R. (2010). Changing competition in market economies. In Morgan, G. Campbell, J. Crouch, C. Pedersen O. \& Whitley, R. (eds.) The Oxford handbook of comparative institutional analysis. Oxford: Oxford University Press. 
Williams, C. \& Lee, S.H. (2011). Entrepreneurial contexts and knowledge coordination within

the multinational corporation. Journal of World Business 46(2): 253-264.

Wood, G. (2013). "Institutional Diversity: Current Issues and Future Contestations”, The

Journal of Comparative Economic Studies, 8, 3-20.

Wood, G., Brewster, C., \& Brookes, M. (eds.) (2014). Human resource management and the

institutional perspective. New York: Routledge.

Wood, G., Dibben, P. \& Ogden, S. (2014). Comparative capitalism without capitalism, and production without workers: the limits and possibilities of contemporary institutional analysis, International Journal of Management Reviews, 16, 384-396.

\author{
Wood, G., \& Lane, C. (2011). Institutions, Change and Diversity. In Lane, C. \& Wood, G. \\ (Eds.), Capitalist diversity and diversity within capitalism. London: Routledge.
}

\footnotetext{
${ }^{\mathrm{i}}$ In fact Amable refers to Scandinavian, rather than Nordic, countries. But as he includes Finland in this group it is more accurately characterized as Nordic.

ii There is a theoretical distinction between the two main types of equity pay: share ownership schemes (a commitment of shares to managers and/or employees), and stock options (where the employee has a right to buy shares at a specific price) - these may be vested (i.e. full title is only obtained after some years' service) or instantly saleable (Kolb, 2012: 16). Kolb (2012) argues that the latter has become increasingly popular. In practice, the distinction between the two types of share ownership (allocations/ share ownership schemes or stock options) is not always clear; many firms themselves using the terms inter-changeably. Furthermore, the relative use of the terms 'share ownership schemes' and 'stock options' varies according to national locale, with the former used more in Europe and the latter more in North America. Hence, for the purposes of this research, we combine these two categories. In practice, they are generally understood to mean the same thing when considered across national boundaries, although there is much variety within these categories according to both category of employee they are aimed at, and how employees respond to them (c.f. Geppert et al. 2013; Ataullah 2014). When we separated the two types out in the data, we found little in the way of significant differences in their relative incidence according to national setting.

iii More formal cluster analysis confirming these intra-European groupings is found in earlier work (Goergen et al., 2012) and was reexamined for this paper.

iv We have experimented extensively with the clusters and find that the removal of single nations does not qualitatively alter our findings.

${ }^{v}$ Given the data are self-reported and collected through the same questionnaire during the same period of time common methods bias might be a matter of concern. Common methods variance, which is attributed to the measurement rather than the constructs of interest, suggests that there may be systematic measurement rather than the constructs of interest and that there may be systematic measurement error and bias. There are several reasons why CMV is unlikely to bias this study. First, the extent that CMV is related to the type of measurement, with attitudinal data being most affected and performance and satisfaction methods being much lower. Cote and Buckley (1987) found CMV in $41 \%$ for attitudinal and $23 \%$ for performance and satisfaction measures. All the variable used in the study are factual with the majority (other than firm size) requiring simple binary responses. They derive from a senior company HRM figure who will have an overview of the firm and its HRM practices. Second, CMV may occur when there is a dependent and independent variable are conflated by measure. This is more likely to occur when the questions asked are not separated in the questionnaire. The questions relating to incentivization and the institutional and other dependent variables are in different sections of the survey (Podsakoff, et al., 2003). Third, we conduct Harman's one-factor test (Podsakoff, et al., 2003). Not surprisingly given the factual nature of the questions asked and their separation in the survey we did not find any one general factor.

${ }^{v i}$ The sectors being - Agriculture, hunting, forestry, fishing; Energy and water; Chemical products; Other manufacturing; Building and civil engineering; Retail and distribution; Transport and communication; Banking, finance, insurance; Personal, domestic, recreational services; Health services; Other services; Education; Local Government; Central Government; and Other.

vii We used the moderation programmes build into STATA, and applied bootstrapping methods to calculate. We note however that there are a variety of programmes enabling moderation analysis and testing.
} 
viii Using data from Botero et al., (2004), Gooderham et al. also find that labour market regulation had a role to play mediating the effects of 'masculinity'. We did not find that labour market regulation to be a statistically significant variable in initial analysis and so have not included it in this study. 